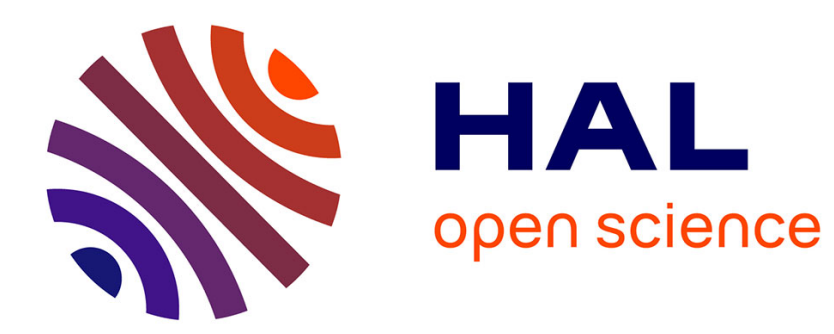

\title{
LASER IRRADIATION EFFECTS IN SUPERCONDUCTORS
}

\author{
C. Falco, I. Schuller
}

\section{To cite this version:}

C. Falco, I. Schuller. LASER IRRADIATION EFFECTS IN SUPERCONDUCTORS. Journal de Physique Colloques, 1978, 39 (C6), pp.C6-529-C6-530. 10.1051/jphyscol:19786237 . jpa-00217659

\section{HAL Id: jpa-00217659 https://hal.science/jpa-00217659}

Submitted on 1 Jan 1978

HAL is a multi-disciplinary open access archive for the deposit and dissemination of scientific research documents, whether they are published or not. The documents may come from teaching and research institutions in France or abroad, or from public or private research centers.
L'archive ouverte pluridisciplinaire HAL, est destinée au dépôt et à la diffusion de documents scientifiques de niveau recherche, publiés ou non, émanant des établissements d'enseignement et de recherche français ou étrangers, des laboratoires publics ou privés. 


\title{
LASER IRRADIATION EFFECTS IN SUPERCONDUCTORS
}

\author{
C.M. Falco and I.K. Schuller ${ }^{+}$ \\ Argonne National Laboratory, Argonne, IlZinois 60439, U.S.A. \\ + Department of Physics, University of Califomie, Los Angeies, 90024, U.S.A.
}

Résumé.- Nous avons étudié le comportement d'un SQUID (Superconducting Quantum Interference Device) à couche mince et d'une boucle supraconductrice bi-métallique sous irradiation d'une lumière laser. Nous trouvons que les résultats expérimentaux peuvent être expliqués par un simple échauffement. Cette interprétation ne suppose pas 1 'existence d'une répartition de quasi-particules qui soit simultanément hors-êquilibre et non-thermique. Nous trouvons également que les effets thermiques empêchent l'observation d'un comportement collectif à basse température suggéré par Bari et Sukhanov.

Abstract.- We have studied the behaviour of a thin film Superconducting Quantum Interference Device (SQUID) and of a bi-metallic superconducting loop under laser light irradiation. We find that the experimental data can be explained by simple thermal heating without assuming the existence of nontherma1 non-equilibrium quasiparticle distribution. We also find that the observation of collective behaviour at low temperature as suggested by Bari and Sukhanov will be hindered by thermal effects.

INTERFERENCE DEVICE ILLUMINATION.- In this experiment, a thin-film rf biased SQUID was illuminated with the He-Ne laser whose power could be varied continuously over several orders of magnitude by means of neutral density filters. The 1 ight was introduced into an electrically and magnetically shielded cryostat using a fiber optic bundle which produced a rectangular 1 ight pattern ( $1 \mathrm{~mm} \times 10 \mathrm{~mm}$ ) on the cylindrical thin film $\mathrm{Sn}$ SQUID as shown in figure 1 .

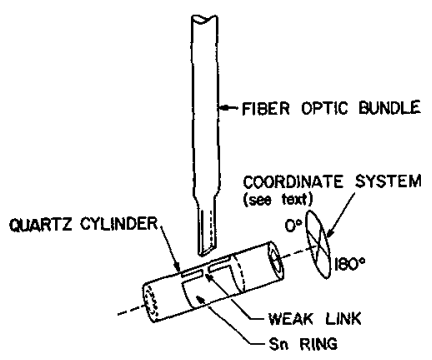

Fig. 1 : Experimental setup.

The SQUID was illuminated at various regions around its circumference and the response measured at a number of temperatures. For simplicity, we only report here data obtained from two regions : illumination directly opposite to the weak link (i.e. with the entire SQUID rotated by $180^{\circ}$ as measured from the weak link) and illumination at the weak link itself. The output from the SQUID was found to be linear over a factor of 20 in applied light po- wer. This behaviour is a characteristic of simple heating. Similarly to Janik et al. /1/ we were able to move through several zeros in the Bessel function response by varying the laser power.

The output response was qualitatively the same for both orientations of the SQUID ; the response was found to be independent of frequency up to some maximum cutoff corresponding to $1.5 \mathrm{~s}$ for illumination at $180^{\circ}$ and $10^{-2} \mathrm{~s}$. for illumination of the weak link $\left(0^{\circ}\right)$. Assuming that the effect of the light is simply to heat the film and substrate, and that the behaviour of the SQUID is determined by the temperature dependence of the weak Iink, one can use thermal conductivity and heat capacity data to calculate the propagation times of heat along the substrate to reach the weak limit. For $\theta=180^{\circ}$ this is calculated to be 5.4s. in reasonable agreement with the measured time of $1.5 \mathrm{~s}$. considering the uncertainties in thexmal conductivity measurements and the fact that part of the heat is conducted away into the liquid helium.

BI-METALIIC LOOP ILLUMINATION.- One junction of a bi-metallic superconducting $\mathrm{Sn}-\mathrm{Pb}$ loop was illuminated with a laser and the resultant current flowing in the loop was measured with a SQUID as shown in figure 2. In the present experiment the sample was maintained at a temperature slightly below the $T_{C}$ of $\mathrm{Sn}$ so that the $\mathrm{Sn}$ was weakly superconducting and the $\mathrm{Pb}$ was strongly superconducting. The experiment was conducted to determine whether illuminating the $\mathrm{Pb}-\mathrm{Sn}$ junction would lead to currents flowing in the 
loop other than those that could be explained by simple heating $/ 2,3,4 /$. This would occur, for example, if the laser illumination caused a local nonequilibrium state which led to a change in phase of the superconducting order parameter.

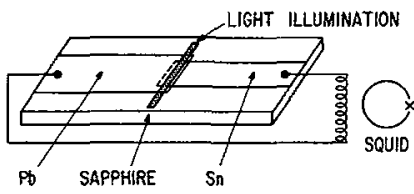

Fig. 2 :Experimental setup for illuminating the bimetallic loop.

Data were taken at a number of temperatures and laser powers. The results are summarized in $\mathrm{fi}-$ gure 3 for three values of temperatures and two values of laser power.

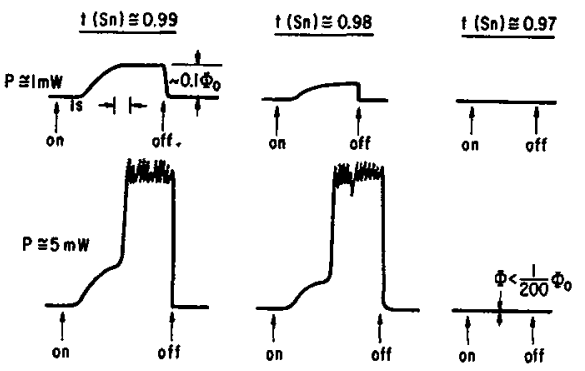

Fig. 3 : Signal from SQUID versus time for pulsed laser illumination for two laser powers and three temperatures.

Close to $T_{c}$, for low values of power, the SQUID detects an induced current due to the illumination. For larger input power, the induced current begins to saturate at a somewhat higher value but then suddenly the SQUID signal increases sharply and becomes noisy. In both cases, there is a time delay between turning on the laser power and the onset of a current. At slightly lower reduced temperature $T / T_{c}=0.98$, the behaviour is qualitatively the same although the maximum induced current is lower. For $\mathrm{T} / \mathrm{T}_{\mathrm{c}}=0.97$, we are unable to induce any detectable current with the maximum laser power we have available.

The behaviour described above is consistent with simple heating. It has been shown $/ 2,3,4 /$ that an unevenly heated bi-metallic superconducting loop gives rise to a circulating current. The magnitude of this current diverges at $T_{c}$ and falls off rapid$1 \mathrm{y}$ at lower temperatures. The sudden appearance of noise at higher temperatures for large values of laser power is consistent with a portion of the sample being driven normal by heating.

SUMMARY.- Our measurements of the effect of $1 \mathrm{ight}$ illumination on thin superconducting films are consistent with simple heating without the necessity of assuming a non-thermal, non-equilibrium distribution of quasiparticle. These experiments also indicate that observation of collective behaviour in superconductors at low temperatures as suggested by Bari and Sukhanov /5/ will be hindered by thermal effects in thin films geometries.

ACKNOWLEDGEMENTS.- This work was supported in part by the U.S. Department of Energy, the U.S. Office of Naval Research, Contract N0014-75-C-0245 P3, and by the National Science Foundation, Grant NSF DMR 75-19544.

\section{References}

/1/ Janik,R., More11i,L., Cirillo,N.C., Lechevet, J.N., Gregory,W.D. and Goodman,W.L., IEEE Trans. Magnetics, MAG-11 (1975) 687

/2/ Zavaritskii,N.V., JETP Lett. 19 (1974) 126

13/ Pegrum,C.M., Guenault,A.M. and Picket,G.R., Low Temperature Physics LT14 (edited by M.Krusius and M. Vuorio), Vo1. 2, P. 513 North Holland, Amsterdam (1975) 513

14/ Falco,C.M., Solid State Comm. 19 (1976) 623

$.15 /$ Bari,V.G. and Sukhanov,A.A., JETP Lett. 21 (1975) 93 